\title{
Understanding Structural Style of Onshore Timor Basin from Detailed Fieldwork
}

\author{
Agus Handoyo Harsolumaksoํㅜ, Benyamin Sapiie ${ }^{1}$, Alfend Rudyawan ${ }^{1}$, Herwin Tiranda ${ }^{2}$, Ezidin Reski ${ }^{3}$ \& Reni \\ Fauziah $^{2}$ \\ ${ }^{1}$ Geodynamic and Sedimentology Study Group, Geology Study Program, Faculty of Earth Sciences and \\ Technology, Institut Teknologi Bandung, Indonesia \\ ${ }^{2}$ Geodynamics Research Group, Insitut Teknologi Bandung, Indonesia \\ ${ }^{3}$ STAR Energy Indonesia, Indonesia \\ Correspondence: Alfend Rudyawan, Geodynamic and Sedimentology Study Group, Faculty of Earth Sciences and \\ Technology, Institut Teknologi Bandung, Jl. Ganesha No. 10 Bandung 40132, Indonesia. E-mail: \\ alfend@geodin.net
}

Received: January 3, 2019

doi:10.5539/mas.v13n4p123

Accepted: February 18, $2019 \quad$ Online Published: March 31, 2019

URL: https://doi.org/10.5539/mas.v13n4p123

The research is financed by Program Penelitian, Pengabdian Kepada Masyarakan dan Inovasi (P3MI) Kelompok Keahlian, Institut Teknologi Bandung.

\begin{abstract}
Hydrocarbon exploration in Eastern Indonesia region is mainly concentrated in the related convergent area such as Timor Basin. This area is characterized by the development of complex imbricate thrust-fold-belt deformation involving sedimentary sequence from the Australia continental margin. However, the exploration has not been successfully found the potential economic reserve. Our study utilized extensive and detailed fieldwork campaign presents the structural style on the onshore region of the Timor Basin. Thick-skinned and thin-skinned thrust faults are both presents in West Timor area divided by the syn-orogenic basin. The change in decolement surface is likely to be caused by inversion structures under the thrust sheets. Our present interpretations indicate that these inversion anticlines structure are likely to occur both onshore and offshore.
\end{abstract}

Keywords: Timor Basin, syn-orogenic, structural style

\section{Introduction}

Timor Basin is close to the Timor Trough in the south of Timor Island (both West Timor and East Timor) and located within the Outer Banda Arc System (SKK MIGAS - LAPI ITB, 2008). The basin covers almost southern offshore of Timor Island (Figure 1). The majority of the area is the type locality of arc-continent collision, which involves Australian continental margin and Banda Arc system. Significant deformation in the island creates imbricated styles of Timor fold-thrust belt system that is formed as a result of a collision between the formerly passive margin of NW Australia and the Banda Arc system. However, several normal faults system occurred in far south of the island within the proximal Australian continental margin due to the loading of the thrust system in the distal margin (Sapiie et al., 2015). The Australian continental margin sequences are well known for hydrocarbon prospectivity since discoveries in the well-established Northwest shelf of Australia hydrocarbon province. The continuity of the margin into the Timor Basin is explorationally more challenging in term of structural setting.

For more than 40 years, hydrocarbon exploration began on Timor Island. The majority of oil and gas seeps are found in East Timor, although most of it was not confirmed, with only fewer occurring in West Timor. In 19931994, Amoseas Indonesia drilled Banli-1 well in West Timor. However, the exploration did not find the potential commercial reserve. The Late Paleozoic-Mesozoic interval has been an important target for hydrocarbon exploration, particularly in the Australian continental margin. The existence of these formations, especially for petroleum system in West Timor and from several wells in the Timor area has brought a bright opportunity for hydrocarbon potential in the Timor Basin. Therefore, understanding the structural style using integrated geology and fieldwork mapping is an important key factor in evaluating and prospecting petroleum basin. 
This study is part of Geodynamics Research Group ITB research in exploring and determining the structural style of the onshore Timor Basin. Thrust and reverse faults The main objectives of the study concentrated on evaluating the different structural pattern occur in many parts of the Timor Basin. In addition, the study will verify and review existing works, previous stratigraphy and dated rocks.

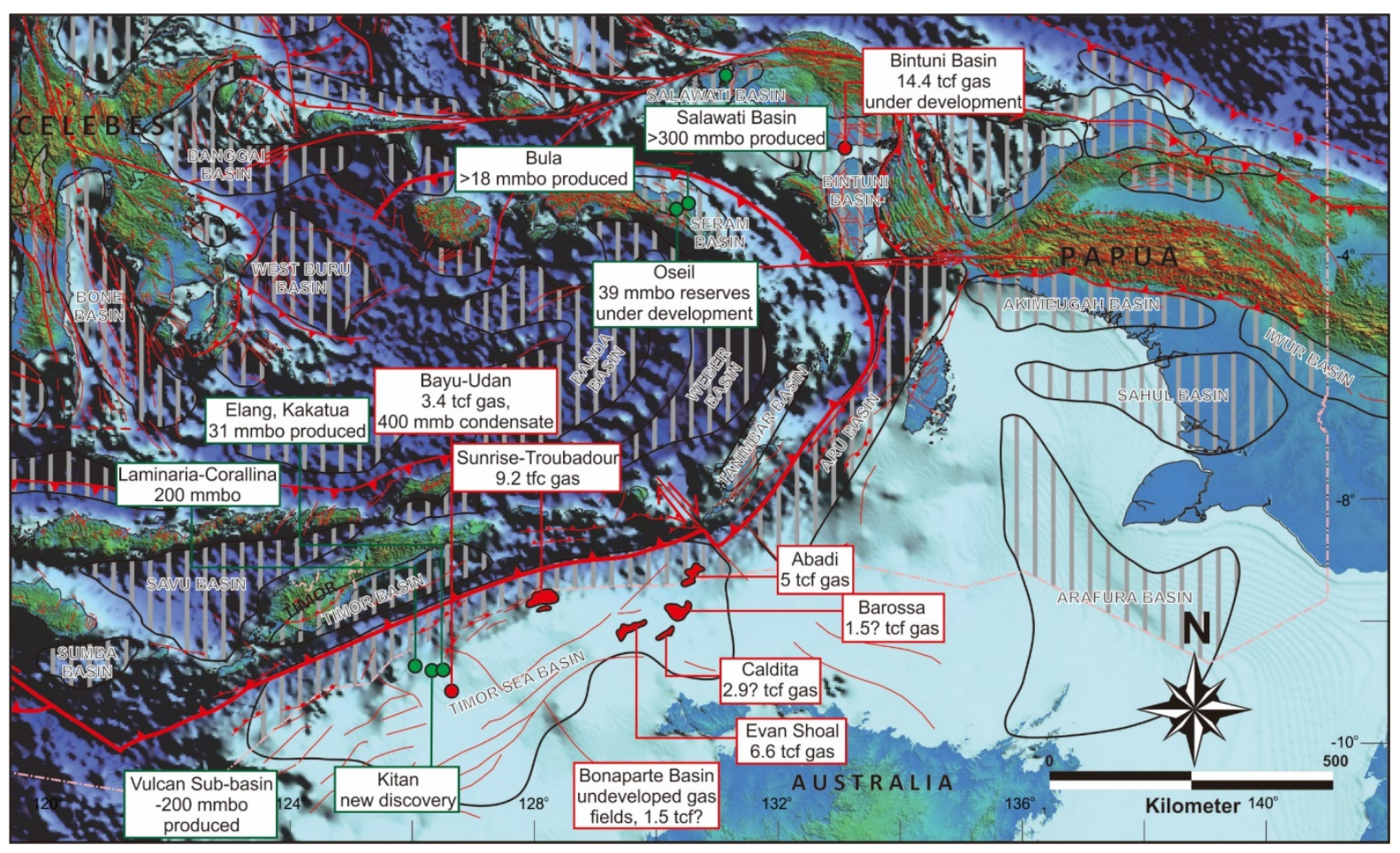

Figure 1. Eastern Indonesia major tectonic elements and Tertiary sedimentary basins with regional petroleum highlights

\section{Method}

The study was conducted using the integrated data acquired from detailed field work in combination with previously interpreted and published data from the regions. Fieldwork was particularly concentrated on analogue outcrop studies in the West Timor field in an effort to redefine stratigraphy of the area. More than 200 outcrop waypoints were visited and observed, particularly in the Kekneno Area, Kolbano Area, and Betun Area, about 150 rock samples were collected and analysed.

\section{Tectonic Setting of the Timor Basin}

The occurrence of Timor Basin in the northern flank of Timor Trough as the part of perisutural foreland basin has been discussed for many years as well as foreland basins in Eastern Indonesia and Papua New Guinea (AudleyCharles, 2004). The thrusting of the imbricate structural pattern in Timor Basin is usually developed within foreland basins resemble that is found in forearc accretionary prisms and in many foreland basins worldwide (Audley-Charles, 2004). The evolution of Timor Basin was begun during the Neogene collision between NW Australia continental margin crust and the fore-arc of the Banda volcanic islands. It led first to the development of Banda Inner Volcanic Arc from about 12 Ma (Audley-Charles, 2011). During the period, Cretaceous-age Indian Ocean lithosphere attached to Australia subducted beneath the Banda forearc of Banda Terrane (Audley-Charles and Harris, 1990) and then followed by collision developed from the more buoyant distal reaches of the Australian continental margin arrived at the trench in the Timor region, resulting in a transition from subduction to collision (Harris et al., 2000). The Timor orogeny creates a $2300 \mathrm{~km}$ long fold and thrust mountain belt reaching $3 \mathrm{~km}$ above sea level after 4 Ma (Audley-Charles, 2011).

The blocking of the Australian continental crust from subducting at the Banda Trench during Timor orogen was probably caused by the $10 \mathrm{~km}$ thick lower crust being driven over the subduction passage at the bottom of the northern limit of the Banda Trench where it met the Banda fore-arc at $6 \mathrm{~km}$ depth (Audley-Charles, 2011). 
Continuation of roll-back of the sub-crustal mantle lithosphere below the Banda Trench by $30 \mathrm{~km}$ after 4 Ma together with the pull-down effect of the subducting sub-crustal mantle lithosphere (Audley-Charles, 2011). Overthrusting of the Banda fore-arc implied by gravity and BIRPS seismicity suggests the Wetar Suture was created by movements of Australian continental lower crust and can be found along the northern of Timor Area (Audley-Charles, 2004; 2011).

The Timor orogeny also creates a $700 \mathrm{~km}$ long and 30-75 km wide depression further south of the imbricated thrust near the shelf edge of NW Australian continental margin. The depression, known as Timor Trough, has 2-3.2 km depths and infilled by marine sediments as the characteristic of a foreland basin (Audley-Charles 1981; Price \& Audley-Charles, 1987; Lorenzo et al., 1998; Hall, 2002; Londono \& Lorenzo, 2004). Several 2D palinspastic models, seismic section, and evidence from bathymetry around Timor Basin showing indication of loading of thrust system in the distal margin of Australian margin outer shelf slope generating the development of Timor Trough, followed by the same time occurrence of reactivation of the older normal faults system at the NW Australian shelf (Sapiie et al., 2015). The depression marks the zone where the distal end of the fold-and-thrust belt has accreted on to down-flexing Australian continental material (Baillie \& Milne, 2014). It, therefore, seems likely that down-flexing took place around 2-3 Ma and that the fold-thrust-belt took place either at that time or shortly thereafter (Baillie \& Milne, 2014).

\subsection{Stratigraphy Of Onshore West Timor}

The onshore stratigraphy of the West Timor is described using integrated outcrop studies from extensive fieldwork in West Timor and from Banli-1 exploration well and several published of literature. In general, stratigraphy of West Timor and the surrounding area has frequently been described in terms of lithotectonic unit as authochthon, para-autochthon, and allochthon structural elements (Audley-Charles 1968; Barber et al., 1977). These lithotectonic units are very important to map particularly the para-autochthon and autochthon of Australian margin stratigraphy series in relation to the hydrocarbon prospectivity of Timor Basin. Stratigraphic nomenclatures comparison of West Timor region is presented in Figure 3.

The Timor allochthon resembles for the emplacement of Banda terrane. Some metamorphic in Timor Island such Lolotoi and Mutis Complexes are described by Harris (1991) as derived from the basement of the Banda forearc on the evidence of the rocks that rest on these metamorphic complexes (Audley-Charles, 2004). The basement is unconformably overlain in different places by volcanic and sedimentary rocks of the Upper Cretaceous to Paleocene Palelo Group, neritic Eocene Limestones, and neritic Lower Miocene Cablac Limestone (AudleyCharles, 2004). All of these formations are entirely allochthonous elements of the Banda Terrane (Audley-Charles, 1968; Audley-Charles \& Carter, 1972; Barber \& Audley-Charles, 1976; Audley-Charles \& Harris, 1990; Harris \& Long, 2000). The wide spread of Bobonaro Complex (Rosidi et al., 1981) in Timor was emplaced onto the allochthon during Late Miocene (Charlton et al., 1991). Recent field geological map in West Timor shows Bobonaro Complex covers 60\% of West Timor region including Rote Island in the southern most of the East Nusa Tenggara province (Figure 2).

Timor para-autochthonous and autochthonous stratigraphy are well defined in Timor by various researchers (Rosidi et al., 1979; AR Livsey et al., 1992; Amoseas, 1995; Harris et al., 2000; Charlton, 2001; Audley-Charles, 2011). Para-authochthonous unit consists of formation rocks from the Australian margin, which existed before the emplacement of allochthonous Banda Terrane. These includes the formation from Permian - Jurassic Gondwana/Kekneno Sequence (Rosidi et al., 1981; Bird \& Cook, 1991; Harris \& Long, 2001) and the passive margin sequence of Jurassic - Miocene Kolbano Sequence (Charlton, 1989; Sawyer et al., 1993; Sani et al., 1995). The Pliocene Tectonic collision followed by production of Bobonaro Complex as tectonic melange and broken formations (Hamilton, 1979; Audley-Charles, 2004; Harris, 2006) lead to emplacement of allochthon Banda Terrane. After the tectonic collision, both allochthon and para-autochthon were unconformably overlain by the syn/post orogenic sediments of autochthon Pliocene, recent sediments (De Smet et al., 1990; Haig \& McCartain, 2007) following the isostatic uplift of Timor Island. A detailed stratigraphic unit of Timor autochthon and paraautochthon with important petroleum system key are described in (Figure 4). 


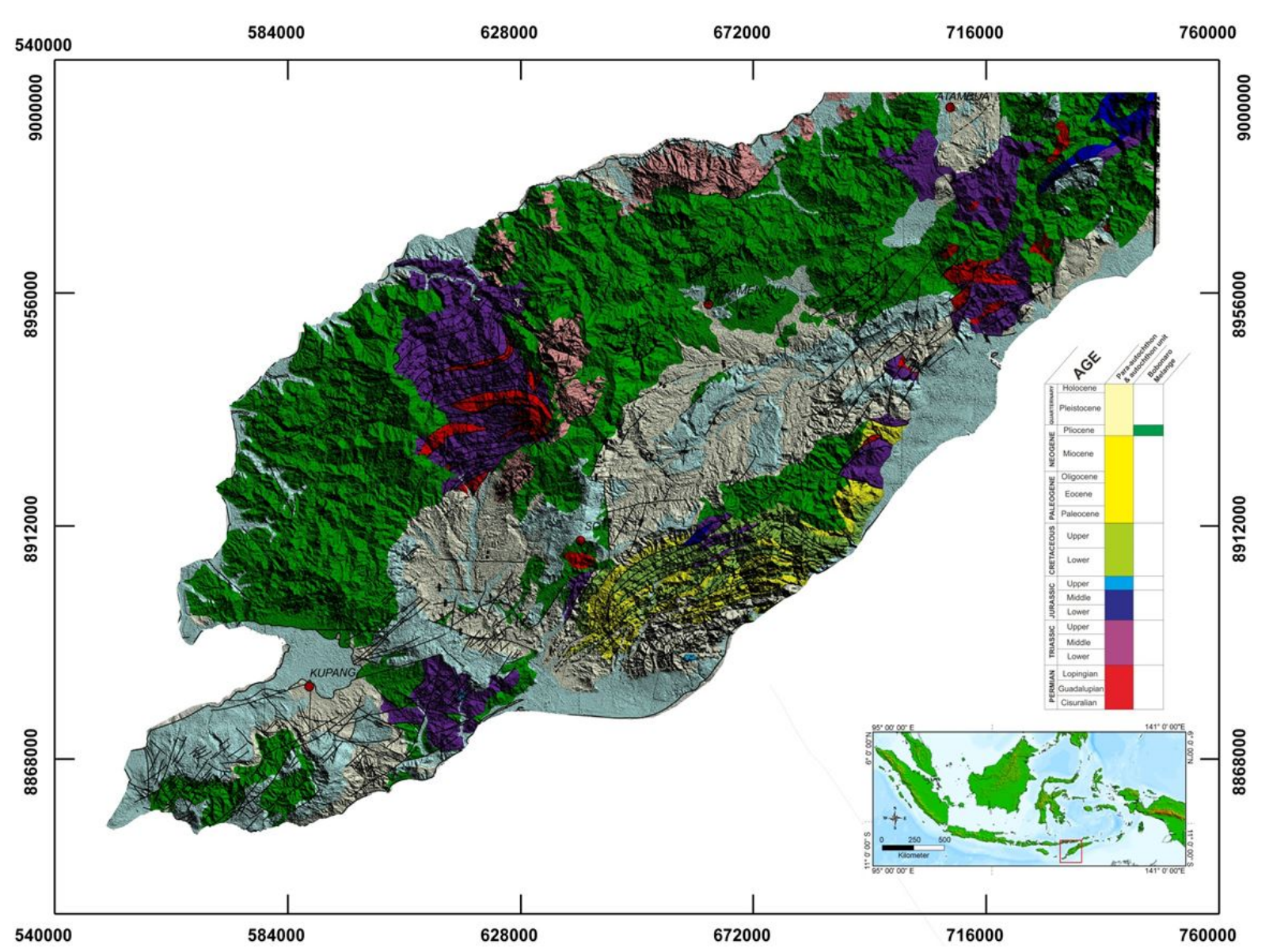

Figure 2. Simplified geological map of West Timor revisited in the light of new data

\subsubsection{Mutis Complex}

The lithology of Mutis Complex consists of schist, phyllite, diabase. and serpentinite often mistaken as the basement of the sedimentary sequence exposed onshore Timor Basin. Various metamorphic rocks, folds, fractures and faults within the Mutis Complex resemble the description of Banda Terrane Basements of Jurassic age (Amoseas, 1995). A more detailed discussion of the Mutis Complex is provided in another paper by Harsolumakso et al (in prep.)

\subsubsection{Atahoc Formation}

Atahoc Formation is predominantly thick dark grey shales interbedded with fine sandstone, consisting of large concretions. Shales are primarily dark grey, but in part red, green, and black, laminated, calcareous, silty beds with 2-3 cm thick. Sandstones are fine grain, beds up to $2 \mathrm{~m}$ thick, and showing basal flute casts. Ammonoid occur occasionally, especially in sandstone beds.

The lower Atahoc Formation consists of interbedded sandstone with the dark-grey shales unit. Sandstones are light grey, fine - medium sand, subrounded grain, well sorted, closed fabric, calcareous, medium porosity, slightly weathered, abundant ammonoid, sharp planar contact, and about 20-200 cm thick. Shales are dark grey, calcareous, and lots of iron concretion. This coarsening upward succession of sandstone turbidites is interpreted to be deposited in the middle fan, an inner fan of the submarine environment. The lithology changes gradually to the upper part of this section. The upper part of Atahoc formation consists of interbedded red shale with greenish-grey shale (intercalation red siltstone occur as intra bed). The shales unit are dominantly red, greenish-grey, and dark grey, but sometimes are black shales in some locations. Calcareous, coral fragment/fossils occur occasionally and sometimes intercalated with siltstone. The upper units of fine-grained turbidite from the Atahoc Formation are deposited in a distal fan of the submarine environment. Sedimentary structures indicate a turbidity current and paleocurrent measurements of flute cast yielded bipolar northeast and southwest directions. The collected 
ammonoid fossil from the field indicates the Early Permian age (Figure 4).

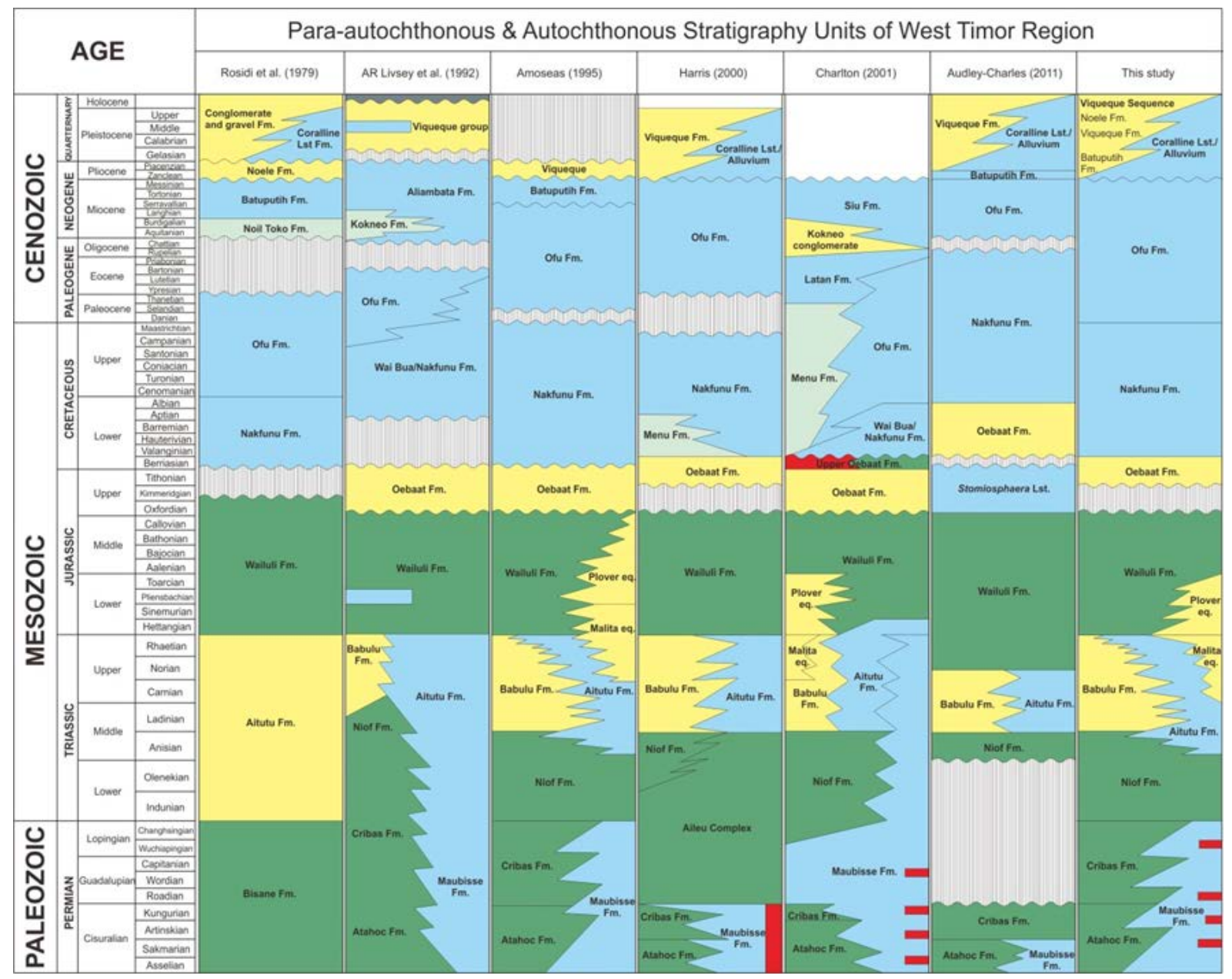

Figure 3. Stratigraphic comparison of West Timor para-autochthonous and autochthonous stratigraphy (modified from various sources)

\subsubsection{Cribas Formation}

Cribas Formation is predominantly thin-bedded sandstones, siltstones, and shales. Sandstones are light-grey, medium sand, subrounded grain, well sorted, closed fabric, calcareous, slightly weathered, contain feldspar, mica, and plant debris material, sharp planar contact, thickness up to 2 meters. Shale unit is dark-grey, calcareous, abundant mica fragments and sometimes founded as slumped bed. Siltstones are dark-grey, friable, and calcareous (Figure 4). In the field it is interpreted to be conformably overlain the Atahoc Formation and interfingers with the Maubisse Formation at the very top.

\subsubsection{Maubise Formation}

The base of Maubisse Formation consists of red limestone and basalts. The limestone contains abundant of crinoidea fossil, packstone to grainstone facies, thickness $10-20 \mathrm{~cm}$, well and thick bedded. The accompanying basalts are often exhibit pillow and amygdaloidal structures. Some alteration occurs as indicated by calcite veins, chlorite and manganese clusters. The upper part of the sequence is dominated by coarse-grained and thicker red limestone compared to the lower part with abundant crinoidea and chepalopoda. Reef facies is also found at the upper part.

Based on petrography analysis, limestone shown by sutured structures (marked by dark brown stylolites) along grain contacts between adjacent bioclast fragments, which indicates strong stress (due to compaction or deformation) during diagenesis. The sample shows grain supported texture with minor micrite matrix. Basalt petrography shows the hypocrystalline porphyritic texture, phenocrysts $(10 \%)$ consist of relic shape of plagioclase 
and mafic minerals, anhedral to subhedral in crystals shape, $0.4-1.5 \mathrm{~mm}$ in size, locally up to $2.5 \mathrm{~mm}$. They present in the groundmass of volcanic glass, microliths of plagioclase, finest crystals of pyroxene $(<0.1 \mathrm{~mm})$, and patches of opaque minerals, which are showed the intersertal texture. The secondary minerals (15\%) present as calcite, silica, chlorite, and iron oxides, they are alteration products of volcanic glass in groundmass, plagioclase, and mafic minerals (Figure 4).

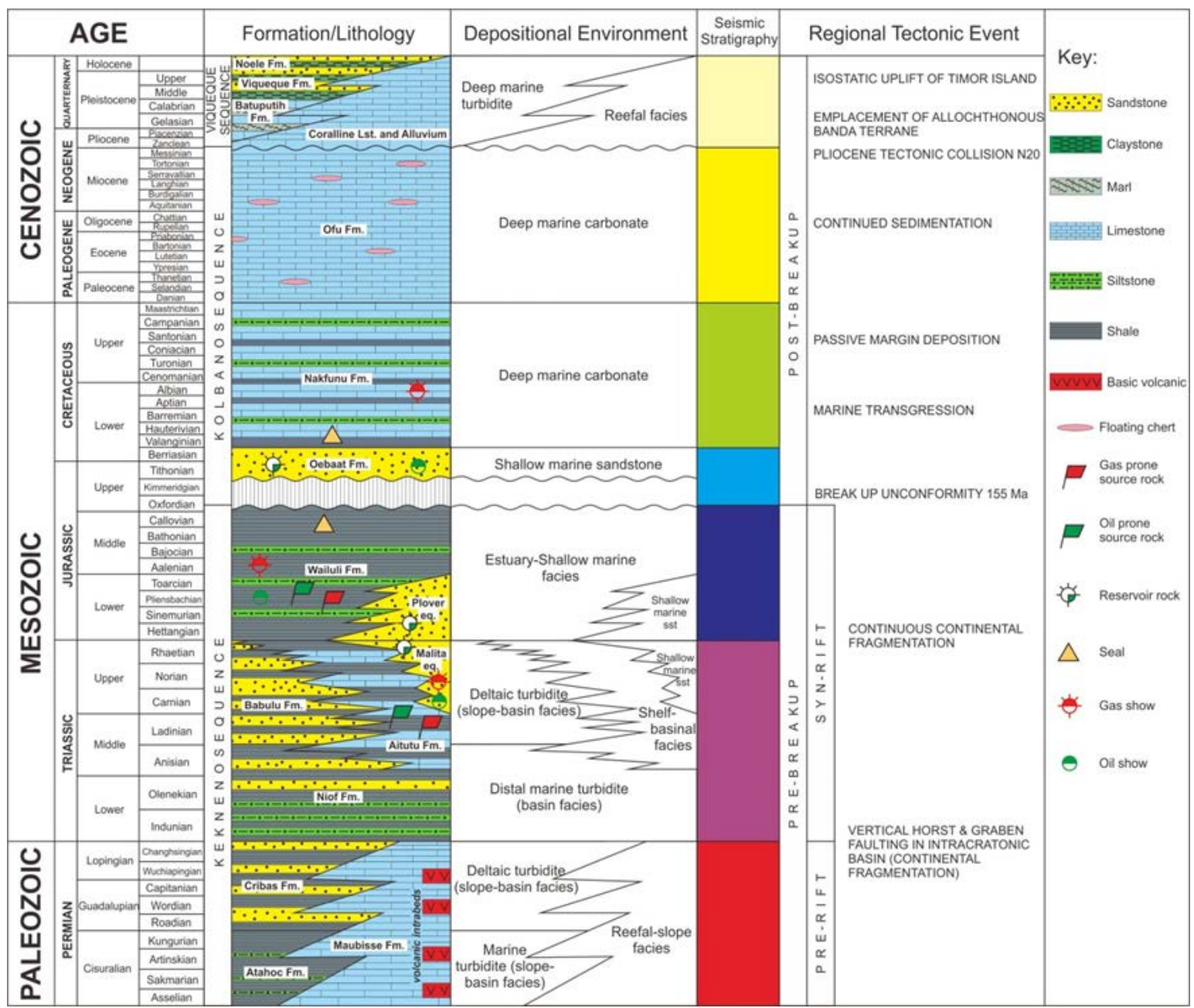

Figure 4. Stratigraphic nomenclature of para-autochthonous and autochthonous in West Timor with major source rock and reservoir sequence

\subsubsection{Niof Formation}

Niof Formation is predominantly shale, interbedded with minor siltstone and sandstone. The uppermost of Niof Formation consists of interbedded dark-grey shales with greenish grey shale and red shales. Shales are varicolored, non-calcareous, slightly weathered, and Hallobia or Daonella occur occasionally. These lithological units are interpreted as Niplelo Member of Triassic Niof Formation. The presence of Hallobia or Daonella indicates that Niof Fomation has Triassic ages. The lower most of Niof Formation consists of interbedded shale with the thin layer of siltstone. Shales are dark-grey (sometimes black), calcareous, a lot of plant debris material, and abundant iron nodule (sometimes chert nodule). These typical lithologies are part of Numfuamolo Member. Niof Formation is deposited in distal fan - fine grained turbidites of the submarine environment based on stratigraphic profile analysis and still close to the landward from abundant plant debris (deltaic turbidites?). The contact between this formation with the older formation is not observed in the field but it seems unconformity (Amoseas, 1995). This Niof Formation conformably overlain by Babulu Formation that could be seen in Noil Pune (Figure 4). 


\subsubsection{Babulu Formation}

Babulu Formation (Figure 4) comprises interbedded sandstone with shales unit, sometimes interbeds with siltstone and limestone. Lower Babulu Formation consists of a thick unit of shales interbeded with sandstone. The grains become coarsening as the succession contact between Triassic Niof Formation and Babulu Formation. These coarsening-upward successions of sandstones turbidite are typical Lower Babulu Formation. Sandstones are light grey, very fine sand, subrounded grain, well sorted, closed fabric, medium porosity, non-calcareous, contain mica grain, current ripple-cross lamination sand, and sharp planar contact. Shales are dark grey, non-calcareous, contain mica and Hallobia or Daonella fossils, slightly weathered, and sharp planar contact. Based on the sedimentary structures and fossils the depositional environment of Lower Babulu Formation is interpreted to be a distal-inner fan of the submarine environment.

The uppermost section of The Babulu Formation comprises sandstones interbeds with shale and siltstone. Sandstones are light-grey, fine-coarse sand, subrounded grain, well sorted, closed fabric, compact, slightly weathered, calcareous cementedgrains dominated by micas, feldspar, quartz, with abundant plant debris material. Various sedimentary structures were recorded such as parallel lamination, load cast, current ripple-cross lamination, bioturbation, and flute cast. Beds are sharp planar contact. Shales are dark-grey, compact, calcareous, and intercalated with cross-laminated siltstone. These units are interpreted to be deposited in the inner-fan submarine environment. Sedimentary structures indicate a turbidity current and paleocurrent measurements of flute cast yielded bipolar NE-SW and NNW-SSE directions.

Based on the petrographic analysis, the sandstone consists of detrital grains that are poorly to medium sorted, angular to sub-rounded, fine to medium-grained $(\sim 0.1-0.5 \mathrm{~mm})$, locally up to $0.8 \mathrm{~mm}$ in size, and long contact to concavo-convex grain contact giving a mature texture impression. Detrital grains consist of quartz, rock fragments, feldspar, opaque, mica, glauconite, locally tourmaline and zircon; they are bounded by carbonate (calcite) cements $(\sim 10 \%)$. The clay matrixs ( $\sim 5 \%)$ with the patches of opaque/iron oxides still present in the rim of grains, some of them recrystallized into illite/sericite in some area of the thin section.

\subsubsection{Aitutu Formation}

Aitutu Formation predominantly by repeated $5-15 \mathrm{~cm}$ grey limestone beds that weathered white, with $5-200 \mathrm{~cm}$ dark shale intrabeds, total thickness of the formation is about $1 \mathrm{~km}$. The limestones are predominantly calcarenite and calcilutite unit, greyish white, clay-fine sand grains; compact, hard, calcareous, slightly weathered, sedimentary structures are load cast, horizontal burrow, parallel lamination, current ripple, with sharp planar contact (Figure 5). Daonella or Hallobia fossils occur occasionally. Shales are dark grey to black, friable, sometimes compact and hard, calcareous, Daonella or Hallobia occur occasionally. At Noil Falas (Falas Traverse), calcilutites are pinkish white. Based on Harsolumakso et al. (1995) the formation consists of pink and white radiolarioan calcilutites interbedded with black shales which is 350-500 m thick.

Based on petrography analysis, the limestone contains abundant thin bivalve shells known as filaments, surrounded by micritic (darker brown) matrix. This wackestone shows mud supported texture, moderately to to poorly sorted, containing bioclasts which dominated by filaments (thin bivalve shells) and some forams. Bivalves (25-30\%) are floating in the micritic matix, broken and unbroken. Few small foraminifers $(<1 \%)$ are locally present, intact, broken, and some of the internal chambers are filled with calcite microspar. Cement (15\%) presents as calcite spar. Matrix (40\%) contains lime mud to microcrystalline calcite (micrite) with brown color, porosity (10-15\%).

The contacts between Aitutu Formation with older formation are not observed in field. However, it is interpreted to be unconformably deposited on top of Permian units as graben filling units. The Triassic Aitutu seems to be interfingers with the coarser clastic facies of the Triassic sediments (Niof Formation and Babulu Formation). Based on stratigraphic profile analysis, Aitutu Formation was deposited in a slope of outer shelf environment.

\subsubsection{Wai Luli Formation}

In Kekneno Area, Wai Luli Formation comprises of interbedded calcarenite and calcilutite with shale, sometimes intercalated with siltstone. Calcarenite and calcilutite are light grey similar to the Aitutu Formation, hard, calcareous, compact, slightly weathered, and sharp planar contact. Shales are greenish dark grey, friable, calcareous, soft, and slightly weathered.

Contacts between Wai Luli Formation with older formation are not observed in the field, however, it is interpreted that this formation conformably overlying Triassic Aitutu Formation. 

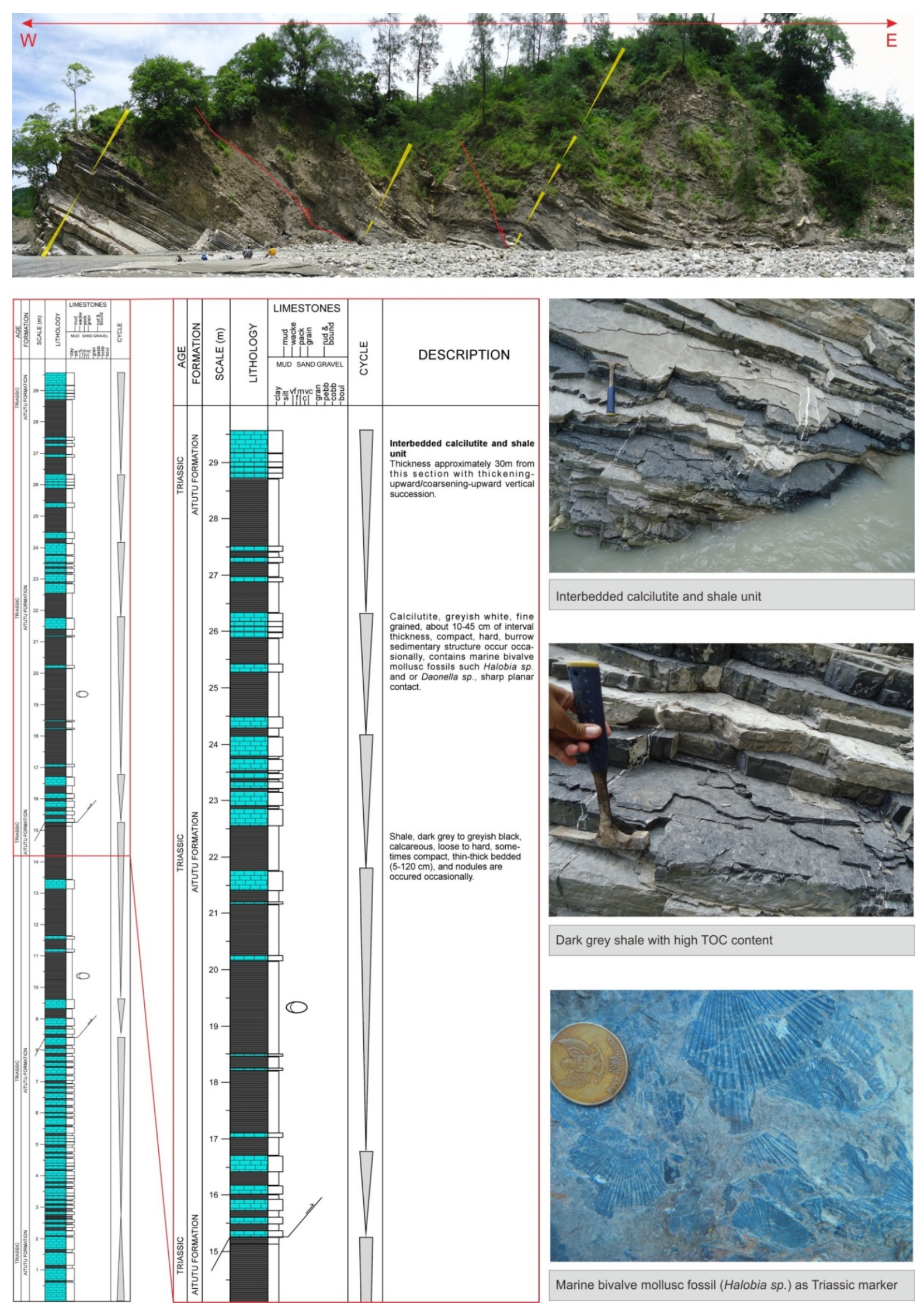

Interbedded calcilutite and shale unit

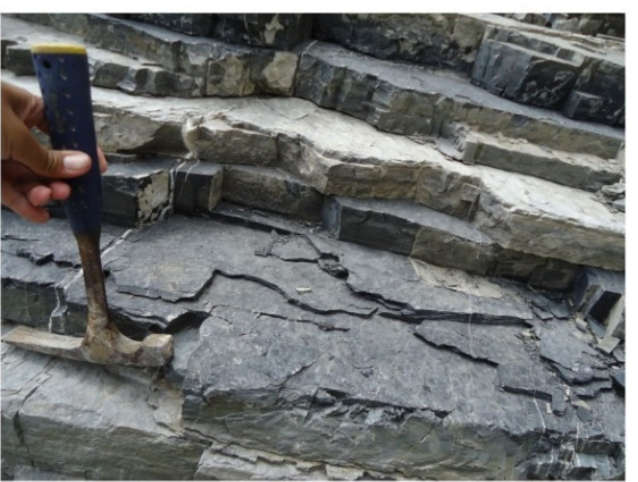

Dark grey shale with high TOC content

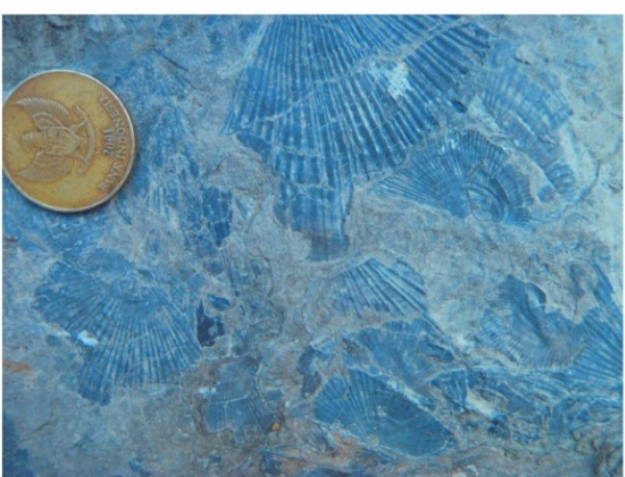

Marine bivalve mollusc fossil (Halobia sp.) as Triassic marker

Figure 5. Example of stratigraphic profile from Triassic Aitutu Formation at Nisnoni River, West Timor 


\subsubsection{Oe Baat Formation}

The Oe Baat Formation, one of the Kolbano series, is exposed in the southern part of fieldwork area as a window. The outcrops of Oe Baat Formation were found in Pasi, Kolbano Area. The outcrop has $15 \mathrm{~m}$ in width, consists of thick massive sandstone in the lower part and claystone in the upper part. The sandstone is yellowish light grey, medium sand grained, closed fabric, well-sorted, rounded, good porosity, layering, and characterized by the presence of glauconite and fossil Belemnites sp. The claystone is light grey, shaly, and with abundant Belemnites sp.

Based on petrography analysis, the unit shows clastic texture, well sorted and open grains contact, locally close contact (point grains contact), consists of detrital grains such as quartz, feldspar, opaque minerals, muscovite, glauconite and small amount of fossil fragments, fine to medium grained $(0.1-0.3 \mathrm{~mm})$, and angular to subrounded in grain shape. The fragments or grains are bounded by matrix of carbonate muds ( 35\%) with patches of iron oxides/opaque minerals to make the blackish brown color. The carbonate mud usually recrystallized into microcrystalline calcite (micrite). The sparry calcite cement ( 10\%) replaced the carbonate mud to fill the space between grains and filled the chamber of fossil fragments.

No stratigraphic relationships with other units were observed. The Oe Baat Formation is interpreted overlie the Wailuli Formation. The formation is covered by syn-orogenic unit (Batuputih Formation) around it. The age of Oe Baat Formation is Tithonian of Late Jurassic.

\subsubsection{Nakfunu Formation}

Nakfunu Formation consists of thinly layered 5-30 cm interbedded siltstone and calcilutite, reddish-brown, claystone and thin-layered chert with distinct, planar and wavy contact. The formation has gently dipping, fractured and faulted. Stratigraphically, the lower part is dominated by interbedded volcanic material, such as tuffaceous claystone. The middle part consists of siltstone, chert radiolarite, and black siltstone And the upper part consist of thinly bedded pink calcilutites.

Based on petrography analysis Tuffaceous claystone is dominated by the clay materials ( $75 \%)$ with the elongate patches of iron oxides/opaque minerals to form the parallel lamination structure. The isotropic characteristic of the clay materials with the relic of flowing structure seem that the clay is mixed with the volcanic glass materials (tufaceous). The clay materials beginning recrystallized and/or altered into illite/sericite or chlorite and they showed the orientation. The bioclastic fragments present in this rock, they usually formed the moldic porosities $(\sim 5 \%)$ and some of them still showed their shell as likely as formanifera fossil. Calcareous Chert is composed by the bioclastic fragments such as Radiolarian fossils and locally small foraminefera fossil, unbroken in shape, fine to medium sand-grained in size $(\sim 0.01-0.3 \mathrm{~mm})$, they are bounded by the mixture of carbonate muds and siliceous materials matrix ( $\sim 30 \%$ ) with the spotted/patches of iron oxides/opaque minerals to form the reddish to blackish brown color. The veins of calcite + iron oxides/opaque mineras appear to cross-cut the rock.

\subsubsection{Ofu Formation}

Lithology consist of pink calcilutite, massive, with intercalation of red chert (not continuous), 6-10 cm, stylolite intensive, with foraminifera fossils. Good outcrop can be found Tiberias Beach (Rote Island). Ofu Formation is composed by massive white or pink calcilutite and fine to medium grained calcarenite with conchoidal to subconchoidal fracture. On an outcrop scale, lamination, cleavage, stylolite, joint, and fracture were easily recognised.

Based on the thin section, calcilutite shows mud-supported texture, with very small amounts of disseminated small bioclasts. Bioclasts are in general still intact and floating in carbonate mud. Various calcite veins and veinlets are present with the different trend, cross-cutting the lithology. They probably represent multiple fracture formation and calcite infilling periods. Based on Sawyer et al. (1993), the formation is Middle Eocene to Early Pliocene in age and deposited in the bathyal environment.

\subsubsection{Bobonaro Formation}

Bobonaro formation was defined by Sawyer et al. (1993) as melange complex is widespread in the West Timor area. The best exposure is found at Noil Falas (Falas Traverse). Bobonaro Formation mainly consists of scaly clay as the ground mass of pre-miocene blocks.

Bobonaro formation is mainly composed of claystone with scaly structure, it shows strong deformation. Besides scaly claystone, there are presences of Pre-Miocene rocks within claystone, such as Maubisse, Mutis, Ofu, Nakfunu, Metan, Cablac, and Haulasi block. There are fault contacts with each other. Based on characteristic in the field;scaly clay structure, mixture of lithology from the various formation, therefore the Bobonaro Formation is interpreted to be formed in the mélange zone. 


\subsubsection{Batuputih Formation}

Batu Putih Formation lithologies are primarily massive white calcilutites or chalks and light grey marls with common plant debris and abundant planktonic foraminifera. Units are soft to firm, and bedding indistinct. Tuffaceous horizons are rare outside of the type locality. There is no luster on freshly cleaved surfaces, which are powdery white. Fracture cleavage is indistinct (Sawyer et.al., 1993). Batu Putih Formation is well exposed in Central Range of West Timor (along the road from Kupang to So'e, near Takari Traverse) and Rote Area.

\subsubsection{Quartenary Limestone and Alluvium}

Quaternary reefal limestones are widespread along studying area. It has overlain all formation at Rote, Kolbano, and Katena Area. Quarternary limestone has described by Sawyer et al. (1993) as the Viqueque Formation, are widely distributed around the coast and locally found inland as raised reef terraces. Based on field observation, the formation consists of white loose limestone that contains large foraminifera, mollusc shells and corals.

\subsection{Geological Structures}

The geological structure of Timor Basin is described using integrated outcrop studies from Alos Palsar Image interpretation, bathymetry analysis, seismic interpretation, extensive fieldwork in West Timor, and various sources of literature,

\subsubsection{Alos Palsar Image}

The geological structure can be delineated from lineament interpretation of the palsar image. Palsar image devided into three regions, they are Katena, South West Timor Sea, and Rote Block. In the South West Timor Sea Region, the rose diagram shows at least two major lineament trends, which are NE-SW and NW-SE Trends. North East Timor Sea Region has the same direction with South West Timor Sea Region, they are NE-SW and NW-SE trends. The NE-SW trends, as similiar direction with Timor Island, is the major trend structure and dominated by thrust fault. The NW-SE trends is perpendicular to Timor Island, it is interpreted as strike-slip or normal fault. In the Rote Regions, the lineaments show two major trends, ENE-WSW and NE-SW. The lineaments data from three regions showing the major direction in NE-SW, as a representation of the major structural elements at West Timor (Figure $6)$.

\subsubsection{Fieldworks}

Detailed fieldworks measurements provided ground-truthing for the Alos Palsar interpretation. Most thrust faults and fold axis have NE-SW hinges with general tectonic transports towards the SE. The best structure styles are exhibited by the thrusting and folding in the Aitutu, Ofu, Nakfunu and Cribas Formation. Normal faults are observed in some of the Mesozoic formations. In many places, pre-Neogene rocks appeared to be experienced stronger deformation. This is manifested in the dominantly NE-SW trending structural contact between the PreNeogene and the Bobonaro Formation that is demonstrated by boudinages, imbricated blocks between intraformation inside clay matrix. To the southwest region of the island the thrust fault complex appear to be deflected to form ENE-WSW direction.

Kolbano area, in the center of the West Timor geology showing different structural style to other areas. Prominent fold and thrust belt with tight frequency involving mainly Ofu and Nakfunu Formation of Cenozoic rocks. Thrust sheets and fold hinges extends for kilometres forming a curvilinear topography. Different structural style exhibited surrounding the Kolbano area. Larger portion of older rocks, Paleozoic and Mesozoic of age, were involved. Reverse fault geometry is different. Faults are difficult to be traced across long distance unlike in Kolbano Area. A slightly less prominent trend exhibited in the island is the NW-SE trend which represent the strike slip faults accompanying the thrusting process or known as tear faults.

\section{Discussion}

The Permian sequences in West Timor region consists of the Atahoc, Maubisse and Cribas Formations are grouped in the pre-rift sequence that filled the intracratonic basin formed by extensional system during continental fragmentation. This sequence is interpreted to be deposited at the continental margins as marine-transitional turbidites interfingering with the reefal-slope facies. Continuous fragmentation resulted in the second group which are the syn-rift sequences that consist of Niof, Aitutu, Babulu and Wailuli Formations. Some relict of extensional fault system appear to cross cut the Atahoc and Cribas Formations. Niof Formation underlain the syn-rift group as distal marine turbidite deposits. Increasing sandstone proportions in the Babulu. 

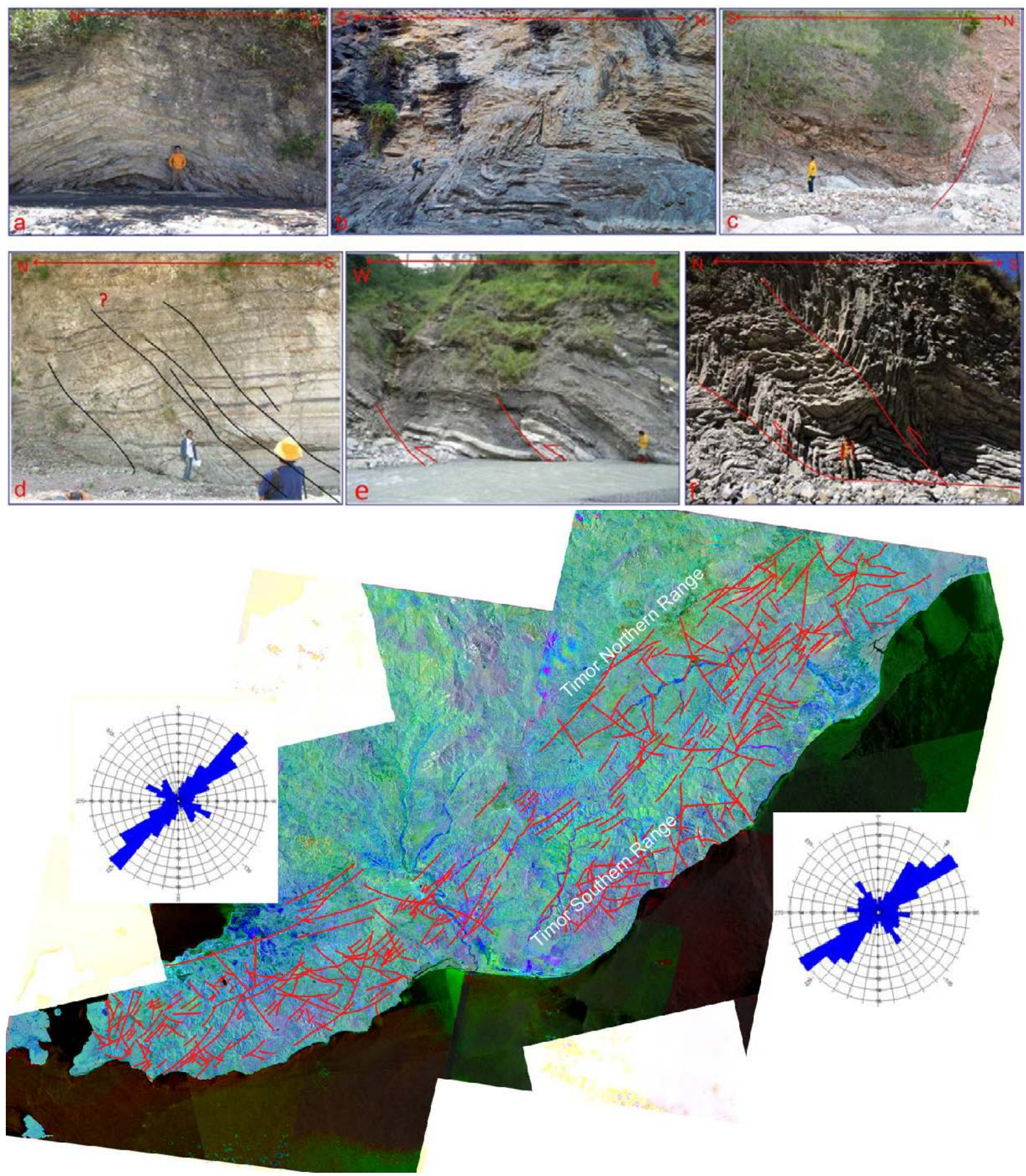

Figure 6. Structural style of West Timor. a) Symmetrical folding of Aitutu Formation at Noil Nisnoni. b) Tight folding of Triassic Aitutu Fm. develops recumbent fold, verging north. c) Normal fault at southern part of the transec (Kolbano Sequence). d) Normal fault in Ofu Fm, exposed at Noil Oetuke. e) Minor reverse fault in Aitutu Fm with steep dipping of fault plane. f) Fold related fault in Triassic Aitutu Fm. at Noil Nisnoni; Lineaments interpretation of Timor Island using Alos Palsar image showing prominent NE-SW trends represented by the fold-thrust belt

Formations suggests that the continental margin received more sediment supply during extension which indicated that the regional uplift occurred in the Gondwana. An overall shallowing upwards sequence of the syn-rift sequence capped by the Wailuli Formation that is interpreted to be deposited in estuary - shallow marine environment before 
a regional break-up unconformity occurred at 155 Ma (Harris, 2000; Audley-Charles, 2011).

Thick, well known, Oebaat Formation was subsequently deposited during the marine transgression post-break up event which was later then overlain conformably by the deep marine carbonate rocks of the Nakfunu and Ofu Formations. The first represent the distal passive margin deposition while the later represents continued sedimentation even after the continental margin become deep ocean basins.

Collision between the Australian Continental Margin with the Banda Arc occurred in the Pliocene. Most of the present day topography is evident to show the scale of the collision. The fold and thrust belt occurred as the prominent mechanism of the uplift. Bobonaro Formation emerges as the subduction fossils that were uplifted during the collision. However different structural style might suggest the different pattern and mechanism as well as the stratigraphy involved in the deformation. Tight fold and thrust belt in thin-skinned mode in Kolbano area involves mainly Upper Mesozoic and Cenozoic sequence (Nakfunu and Ofu Formation). Detachment level is interpreted to be the regional break-up unconformity, therefore no older Mesozoic sequences were involved. However, the Paleozoic and lower Mesozoic units are prevalent away from the Kolbano Area. These sequences have been brought up by the reverse fault detaching on a much deeper décollement surface (Figure 7). This reflected in a more thick-skinned attitude of the imbricate fault planes. Quite a number mud volcanoes are observed in the northern West Timor area that could imply a fault related mud plumbing system.
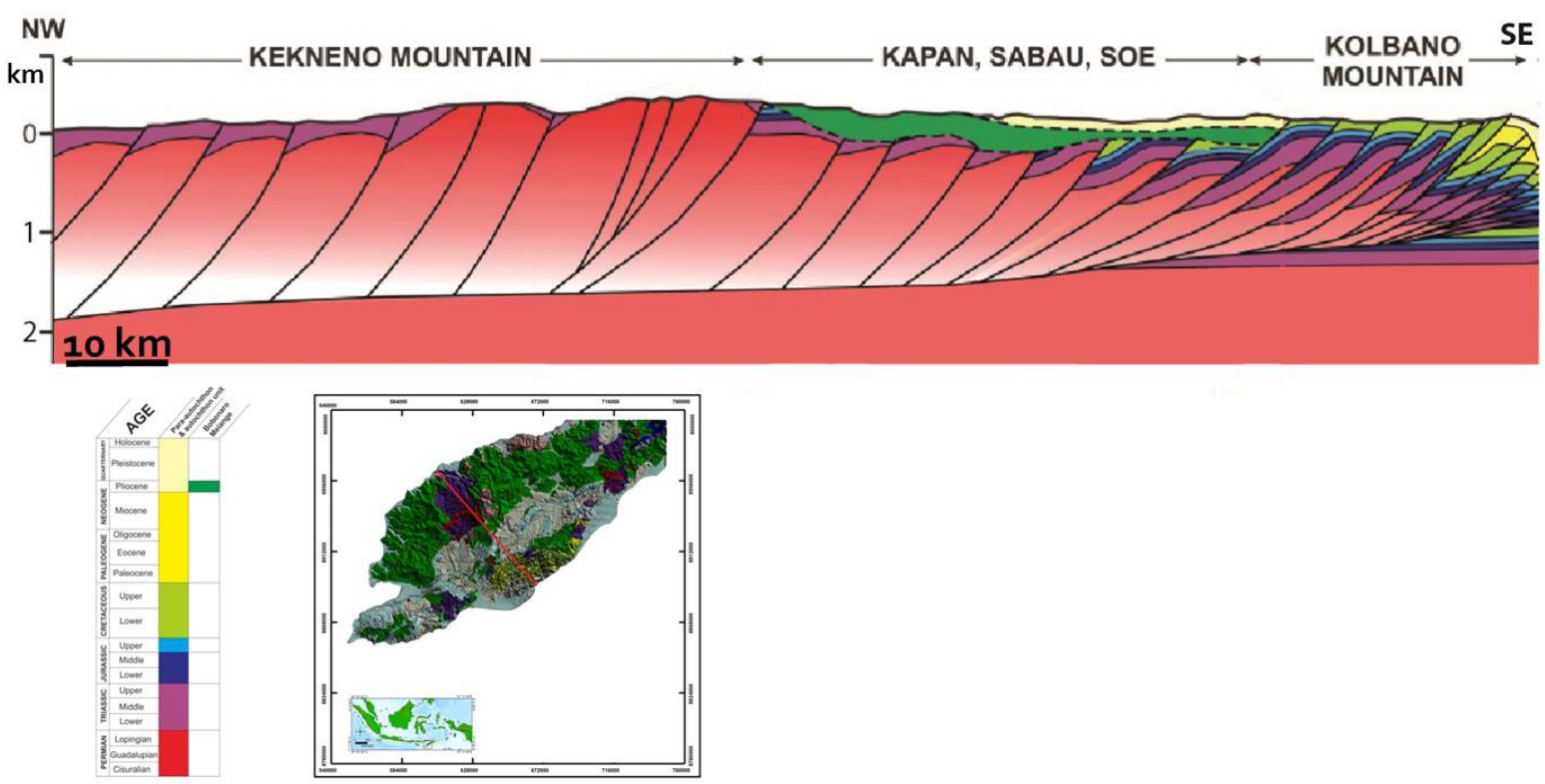

Figure 7. Integrated cross-section through Timor Island towards the Timor Sea and NW Shelf of Australian Passive Margin showing two different structural style; thick-skinned in the north and thin-skinned thrusting in the south

The two different structural style indicated by a transition area reflected as depression between the Kolbano area and higher ground of Mutis Complex. The basin was subsequently filled by syn orogenic sequence that consist of the Batuputih, Viqueque and Noele Formations. This transition from deep to shallower detachment level is interpreted due to the inversion structures below the Kolbano thrust sheets in the Kolbano area (Figure 7).

Thick-skinned nature of the thrust faults in the northern West Timor has brought almost all of the strata that are important for the petroleum system up to the surface thus diminishing the hydrocarbon potential in the northern West Timor. This could explain why there are less oil seeps in West Timor compared to East Timor. On the other hand, change in decollement surface preserved the older rocks under the Kolbano sequence thus making the south and southeast region of the Timor Basin maintain the hydrocarbon potential.

\section{Acknowledgments}

We would like to thanks thank the staff and assistant of the Geodynamics Research Group, Geology Study Program ITB and the Faculty of Earth Sciences and Technology, Insitut Teknologi Bandung for their support and help in conducting this study. The work was supported by a grant from Program Penelitian dan Pengabdian pada 
Masyarakat dan Inovasi (P3MI) LPPM ITB.

\section{References}

Amoseas Indonesia Inc. (1995). SOE PSC, West Timor-Nusa Tenggara Timur, Final Relinquishment Report.

Audley-Charles, M. G. (1981). Geometrical problems and implications of large-scale overthrusting in the Banda arc-Australian margin collision zone. In McClay, K., \&Price, N. J. (Eds), Thrust and Nappe Tectonics. Geological Society, London, Special Publications, 9, 407-416.

Audley-Charles, M. G. (2004). Ocean trench blocked and obliterated by Banda forearc collision with Australian proximal continental slope. Tectonophysics, 389, 65- 79.

Audley-Charles, M. G. (2011). Tectonic post-collision processes in Timor. Geological Society of London, Special Publications, 355, 241-266.

Audley-Charles, M. G., \& Carter, D. J. (1972). Palaeogeographical significance of some aspects of Palaeogene and early Neogene stratigraphy and tectonics of the Timor Sea region. Palaeogeography, Palaeoclimatology, Palaeoecology, 11, 247- 264.

Audley-Charles, M. G., \& Harris, R. A. (1990). Allochthonous terranes of the southwest Pacific and Indonesia. Philosophical Transactions Royal Society of London, 331, 571-587.

Audley-Charles, M. G. (1968). The geology of Portuguese Timor: Geological Society of London Memoir 4.

Baillie, P., \& Milne, C. (2014). New insights into prospectivity and tectonic evolution of the Banda Arc: evidence from broadband seismic data. Proceedings of the Indonesian Petroleum Association, 38.

Barber, A. J., Audley -Charles, M. G., \& Carter, D. J. (1977). Thrust tectonics on Timor. Geological Society of Australia Journal, 24, 51-62.

Barber, A. J. \& Audley-Charles, M. G. (1976). The significance of the metamorphic rocks of Timor in the development of the Banda Arc, Eastern Indonesia. Tectonophysics, 30, 119-128.

Bird, P. R., \& Cook, S. E. (1991). Permo-Triassic successions of the Kekneno area, West Timor: implications for palaeogeography and basin evolution. Journal of Southeast Asian Earth Sciences, 5, 359-371.

Charlton, T. R. (1989). Stratigraphic correlation across an arc-continent collision zone: Timor and the Australian Northwest Shelf. Australian Journal of Earth Sciences, 36, 263-274.

Charlton, T. R. (2001). The petroleum potential of West Timor. Proceeding of Indonesian Petroleum Association, 28, 301-317.

Charlton, T. R., (2002). The petroleum potential of East Timor. APPEA Journal, 2002, 351-369.

Charlton, T. R., Barber, A. J., \& Barkham, S. T. (1991). The structural evolution of the Timor collision complex, eastern Indonesia, Journal of Structural Geology 13, 489-500. Charlton, T.R. and Wall, D., 1994, New biostratigraphic results from the Kolbano area, southern West Timor: implications for the Mesozoic -Tertiary stratigraphy of Timor. Journal of Southeast Asian Earth Sciences, 9, 113-122.

de Smet, M. E M., \& Fortuin, A. R. et al. (1990). Detection of collision-related vertical movements in the Outer Banda Arc (Timor, Indonesia) using micropaleontological data. Journal of Southeast Asian Earth Sciences, 4, 337- 356.

Haig, D. W., \& McCartain, E. (2007). Carbonate pelagites in the post-Gondwana succession (Cretaceous-Neogene) of East Timor. Australian Journal of Earth Sciences, 54, 875-897.

Hall, R. (2002). Cenozoic geological and plate tectonic evolution of SE Asia and the SW Pacific: computerbased reconstructions, model and animations. Journal of Asian Earth Sciences, 20, 353-434.

Hamilton, W. (1979). Tectonics of the Indonesian Region. U.S. Geological Survey Professional Paper,1078.

Harris, R. A., \& Long, T. (2000). The Timor ophiolite, Indonesia: model or myth? In: Dilek, Y., Moores, E. M., Elthon, D. \& Nicolas, A. (eds) Ophiolites and Oceanic Crust: New Insights from Field Studies and the Ocean Drilling Program. Geological Society, America, Special Paper, 349, 321-330.

Harris, R. A. (1991). Temporal distribution of strain in the active Banda orogen: a reconciliation of rival hypotheses. Journal of Southeast Asian Earth Sciences, 6, 373-386.

Harris, R. A. (2006). Rise and fall of the Eastern Great Indonesian arc recorded by the assembly, dispersion and accretion of the Banda Terrane, Timor. Journal of Gondwana Research, 10, 207-231. 
Harris, R. A., Kaiser, J., Hurford, A. J., \& Carter, A. (2000). Thermal history of Australian passive margin sequences accreted to Timor during Late Neogene arc-continent collision, Indonesia. Journal of Asian Earth Science, 18, 47-69.

Jin, L., Zhiseng L., Dongliang, W., Jian L., \& Ying, Z. (2011). Nitrogen isotopic geochemical characteristic in natural gas of Tarim Basin. AAPG Search and Discovery Article. Hedberg Conference Natural Gas Geochemistry, Beijing, China.

Livsey, A. R., Duxbury, N., \& Richards, F. (1992). The geochemistry of Tertiary and pre-Tertiary source rocks and associated oils in Eastern Indonesia. Proceedings of the Indonesian Petroleum Association 21, 3-16.

Londono, J., \& Lorenzo, J. M. (2004). Geodynamics of continental plate collision during late Tertiary foreland basin evolution in the Timor Sea: constraints from foreland sequences, elastic flexure and normal faulting. Tectonophysics, 392, 37-54.

Lorenzo, J. M., O’Brien, G. W., Stewart, J., \& Tandon, K. (1998). Inelastic yielding and forebulge shape across a modern foreland basin: North West Shelf of Australia, Timor Sea. Geophysical Research Letters, 25, 14551458.

Price, N. J., \& Audley-Charles, M. G. (1987). Tectonic collision processes after plate rupture. Tectonophysics, 140, 121-129.

Rosidi, H. M. D., Suwitodirdjo, K., \& Tjokrosapoetro, S. (1979). Geologic Map of Kupang-Atambua Quadrangles, Timor 1:250,000. Bandung: Pusat Penelitian dan Pengembangan Geologi.

Rosidi, H. M. D., Suwitodirdjo, K., \& Tjokrosapoetro, S. (1981). Geologic Map of Kupang-Atambua Quadrangles, Timor 1:250,000 (with accompanying brochure). Bandung: Pusat Penelitian dan Pengembangan Geologi.

Sani, K., Jacobson, M. L., \& Sigit, R. (1995). The thin-skinned thrust structures of Timor. Proceedings of the Indonesian Petroleum Association, 24, 277-293.

Sapiie et al. (2008). Map of tectonics and structures of Indonesia. Jakarta: Published by DITJEN MIGAS, SKK MIGAS, and IAGI, Published by IAGI.

Sapiie, B., Kurniawan, A., Pamumpuni, A., Danil, D., Gunawan, I., Tiranda, H., \& Reski, E. (2015). New insight of structural evolution of the Timor Island and Australian continental margin. Poster session presented at the Annual Convention of Geological Society of America, Baltimore, Maryland, USA.

Sawyer, R. K., Sani, K., \& Brown, S. (1993). Stratigraphy and sedimentology of West Timor, Indonesia. Proceedings of the Indonesian Petroleum Association, 22, 1-20.

Waples, D. W., \& Machihara, T. (1991). Biomarkers for geologists: A practical guide to the application of steranes and triterpanes in petroleum geology. AAPG Methods in Exploration Series, 9, 9.

\section{Copyrights}

Copyright for this article is retained by the author(s), with first publication rights granted to the journal.

This is an open-access article distributed under the terms and conditions of the Creative Commons Attribution license (http://creativecommons.org/licenses/by/4.0/). 